\title{
TROPHOBLAST INVASION AND UTERIOIMPLANTATION GROWTH IN EARLY RAT GESTATION REQUISITE ADRENOMEDULLIN
}

\author{
KANCHI RAVI PADMA, PENCHALANENI JOSTHNA*
}

Department of Biotechnology, Sri Padmavati Mahila VisvaVidyalayam, Women's University, Tirupati, Andhra Pradesh, India. Email: thulasipadi@gmail.com

Received: 01 January 2018, Revised and Accepted: 11 January 2018

\section{ABSTRACT}

Objective: Adrenomedullin (ADM) is a currently exposed hypotensive peptide that is articulated in a variety of cell and tissue types. The existence of ADM has been immunohistochemically demonstrated in pathologic uterioimplantation regions, but no systematic study of ADM expression in early pregnancy in uterioimplantation region has been reported.

Methods: Rats on the gestational day 2 were implanted subcutaneously with osmotic (Alzet) minipumps delivering 125 and $250 \mu \mathrm{g}$ rat/day/of $\mathrm{AM}_{22-52}$ and were killed on the gestational day 9 . We have ascertained the hypothesis that ADM, a multiregulatory ubiquitous peptide hormone, works as a trophoblast pro-invasion factor.

Results: We confirmed ADM significance in in vitro assay using ACH-3P cell line, which is first-trimester trophoblast cell line.

Conclusion: Our data support the conception that ADM is involved in the human implantation process through regulating trophoblast proliferation and differentiation.

Keywords: Adrenomedullin, Cell proliferation, Trophoblast, Pregnancy, Implantation.

(C) 2018 The Authors. Published by Innovare Academic Sciences Pvt Ltd. This is an open access article under the CC BY license (http://creativecommons. org/licenses/by/4. 0/) DOI: http://dx.doi.org/10.22159/ajpcr.2018.v11i5.24555

\section{INTRODUCTION}

Implantation, trophoblast growth, and progression are imperative to the overall well-being of the fetus and are controlled by a range of signals, including steroids and growth factors. Adrenomedullin (ADM), a potent multiregulatory peptide, has been established previously to exert various actions on cellular growth, central nervous system, and endocrine system. Currently, ADM has been concerned in a multiplicity of reproductive functions, specifically during pregnancy. In the human, plasma ADM levels were raised during pregnancy and reduced at term [1-4]. This augmentation in ADM levels happened immediately after implantation, and subsequently, decrease of ADM took place in both plasma [5,6] and amniotic fluid [7] later in gestation. In addition, Moriyama et al. [8] described that the expression of ADM in cytotrophoblasts is most copious in the first-trimester human placenta. These observations linked the involvement of ADM during early placentation and fetal growth in human pregnancy. ADM, CRLR, and RAMPs are extensively expressed in human reproductive tissues comprising ovary, oviduct, endometrium, placenta, and testis [9].

The ADM gene and its protein product are extremely preserved across species, including human, rat, and porcine [10]. ADM has an exclusive six amino acid residue ring structure and C-terminal amidation related to calcitonin gene-related peptide and amylin [11]. The six-membered amino acid ring structure (amino acid 16-21) connected by one disulfide bond (between Cys16 and Cys21) was initiated to be responsible for the vasodilator activity in human (h) AM [11,12]. Champion et al. [12] demonstrated that hAM (15-22) possessed vasodepressor activity analogous to that of hAM (1-52) in the systemic arterial pressure of the rat. However, hAM (22-52) lacked vasodepressor activity when injected intravenously in doses up to $300 \mathrm{nmol} / \mathrm{kg}[12,13]$. Administration of synthetic hAM antagonist, compiled of amino acids 22-52, blocked the reduced peripheral vascular resistance associated with hAM (1-52) therapy. Thus, human AM (22-52) is a specific antagonist to the vasodilator activity of hAM (1-52). It is not acknowledged whether a naturally occurring form of hAM (22-52) antagonist subsists.
With outlook to human pregnancy, Macri et al. [14] identified ADM peptide in second-trimester human amniotic fluid by RIA, and we examined ADM peptide in first trimester in rodent blood by chemiluminescence immunoassay (CLIA) method. CLIA detection using Microplate luminometers provides a sensitive, high throughput, and economical alternative to conventional colorimetric methodologies, such as enzyme-linked immunosorbent assays.

The impact of $\mathrm{AM}_{22-52}$ infusion on early implantation formation and fetal growth, however, was not addressed in the previous studies. We, therefore, hypothesized that inhibition of endogenous ADM function during implantation and early placental development (days 2-8 of gestation) would result in impaired implantation formation and fetal growth restriction in rats. Early pregnancy in rodents is characterized by a progressive interaction between the embryo and the maternal compartment. Rodent uterine epithelium around the embryo undergoes apoptosis in response to the presence of the blastocyst [15-17]. The blastocyst signals that induce the apoptotic cascade, as well as the genes that regulate this local event, are still unknown. Recent reports suggest that AM is a regulator of cell growth and differentiation [4] and that it plays a potent protective role against apoptosis and in maintaining cellular integrity. Hence, normal ADM function is required to prevent apoptosis and sustain normal implantation, placental development, and fetal growth.

We consequently hypothesized that the fetal and placental growth restriction in ADM-antagonized rats perhaps occurs through enhanced apoptosis in the uteroimplantation tissues during early development. At the molecular level, apoptosis is greatly regulated and is mainly coordinated by the activation of the aspartate-specific cysteine protease (caspase) cascade. Two reported pathways lead to the activation of caspases [18-20]. The first is the mitochondrial (receptor-independent) pathway, and the second engrosses interaction of death receptor and its ligand. Both proapoptotic (Bax) and antiapoptotic Bcl-2 (Bcl-2 and BclXL) family members control the mitochondrial pathway [21] by 
modifying the cytochrome $c$ release from mitochondria into cytosol. The cytosolic cytochrome $c$ then persuades oligomerization of Apaf$1[22]$, resulting in the activation of procaspase-9, which then activates procaspase-3 resulting in apoptosis. The second is the extrinsic pathway through the induction of Fas/Fas ligand, causing activation of $\mathrm{p} 53$, which then can directly activate procaspase- 3 . In our present study, the ADM-antagonist was continuously infused during days 2-8 of gestation, and on day 9, we assessed changes in caspase-3, Bcl-2 family proteins, and extrinsic pathway mediator p53 for apoptosis.

\section{METHODS}

\section{Animal maintenance}

Animal studies were performed as per the Institute Animal Ethics Committee regulations and approved by the committee (Reg. No. 1677/ PO/a/12/CPCSEA/SPMVV-IEC/2014/01). Female rats of Wistar strains purchased from Sri Venketeswara Enterprises, Bengaluru, India, with 200-250 g weights were used for this study. Rats were placed in polypropylene cages covered with a metal grid. All animals were maintained in climate-controlled room temperature with sufficient aeration and proper lightening and were fed standard rat chow with water to drink.

\section{Experimental treatment protocol}

Female Wistar rats (Rattus norvegicus), weighing $200 \mathrm{~g} \pm 280 \mathrm{~g}$, were used for the experiment. Three to four pregnant rats were used for each of the experimental study. Female rats were mated with male proven breeders. The next day morning, collecting of vaginal secretion with a plastic pipette filled with $10 \mu \mathrm{L}$ of normal saline $(\mathrm{NaCl} 0.9 \%)$ by inserting the tip into the rat vagina. One drop of vaginal fluid was placed on glass slides, and the unstained material was observed under a light microscope $[23,24]$. Two females of proestrous stage were paired with a male overnight, and in the next morning, males were removed and females were assessed for the presence of sperms in the vaginal flush. Animals with positive sperm in the flushes are designated as day 1 of gestation.

\section{Infusion of osmotic (ALZET) pumps}

The mean \pm SEM body weight was $224 \pm 250 \mathrm{~g}$ in the rats on the day 2 of gestation (study initiation). On day 2 of gestation, osmotic minipumps (model 2001 Alzet pump; $1.0 \mu \mathrm{l} / \mathrm{h}$ ) were inserted subcutaneously into the dorsum of pregnant rats while the animals were under anesthesia (anesthesia consisted of a combination of ketamine [ $45 \mathrm{mg} / \mathrm{kg}$ ] and xylazine $[5 \mathrm{mg} / \mathrm{kg}])$. The minipumps were filled with saline alone or with saline containing different concentrations of $\mathrm{AM}_{22-52}$. These concentrations were chosen based on the earlier findings of Witlin et al. [26] and Penchalaneni et al. [25] to deliver $\mathrm{AM}_{22-52}$ at 125 and $250 \mu \mathrm{g} / \mathrm{rat} /$ day

\section{CLIA for serum steroid hormone levels}

Blood samples were collected in sterile tubes using disposable needle and syringe. Blood was collected through cardiac puncture followed by serum extraction for the measurement of steroid hormones, estrogen, and progesterone which were estimated through CLIA by the method of Coombes et al. (1981).

\section{Western blot analysis}

Equal amounts of protein $(30 \mu \mathrm{g})$ were separated by various appropriate concentrations of SDS-PAGE: $12 \%$ for Bcl-2, Bax, p53, and $15 \%$ for caspase-3. Gels containing the SDS-PAGE-separated proteins were equilibrated in transfer buffer $(25 \mathrm{mM}$ Tris, $\mathrm{pH} 8.3,190 \mathrm{mM}$ glycine, $0.05 \%$ SDS, and $20 \%$ methanol) and were electrotransferred to nitrocellulose membranes. Membranes were blocked with TTBS buffer (20 mM Tris, pH 7.4, $150 \mathrm{mM} \mathrm{NaCl}$, and $0.05 \%$ Tween 20) containing $5 \%$ non-fat dry milk for $1 \mathrm{~h}$ and were washed with TTBS buffer. For the detection of apoptotic and antiapoptotic proteins, polyvinylidene difluoride was incubated in the antibodies to Bcl-2, Bax, p53, and caspase-3. After exposure to horseradish peroxidase-conjugated anti-rabbit IgG (caspase-3, Bax, p53, and Bcl-2) secondary antibodies (diluted 2000-fold to 5000 -fold) for $1 \mathrm{~h}$, blots were washed and developed by enhanced chemiluminescence. Each blot was stripped with $100 \mathrm{mM}$ glycine and $\mathrm{pH} 2.3$ and was reprobed with $\beta$-actin to normalize for any variations incorporated in protein loading. Densities of each protein of interest were expressed as a ratio to that of $\beta$-actin.

\section{Cell culture}

ACH-3P (American Type Culture Collection) is a immortalized cell line from human placenta (Hiden et al., 2007) and is frequently used as a model for the study of EVCT invasion (Janneau et al., 2002; Wolf et al., 2010). The immortalized ACH-3 cell line is derived from a primary culture of first-trimester normal EVCT isolated from human placenta. The cell lines were cultured in Dulbecco modified Eagle medium -high glucose (\#AL007, Himedia), fetal bovine serum (\#RM10432, Himedia), and $37^{\circ} \mathrm{C}$ incubator with humidified atmosphere of $5 \% \mathrm{CO}_{2}$ (Healforce, China).

\section{Materials used}

MTT reagent $(5 \mathrm{mg} / \mathrm{ml})$, dimethyl sulfoxide (DMSO), camptothecin, D-PBS, 96-well plate for culturing the cells (From Corning, USA) and T25 flask (\# 12556009, Biolite - Thermo) DMSO, PBN, and ACH-3P cell line were used.

\section{Principle of MTT assay}

MTT assay is a colorimetric assay used for the determination of cell proliferation and cytotoxicity, based on the reduction of the yellowcolored water-soluble tetrazolium dye MTT to formazan crystals (Fig. 1). Mitochondrial lactate dehydrogenase produced by live cells reduces MTT to insoluble formazan crystals, which on dissolution into an appropriate solvent exhibits purple color, the intensity of which is proportional to the number of viable cells and can be measured spectrophotometrically at $570 \mathrm{~nm}$.

The purple formazan formed is dissolved using DMSO to form purplecolored solution and it is read at $570 \mathrm{~nm}$, and data are analyzed by the graph obtained between cell number and absorbance. From the curve, we can know the $\mathrm{IC}_{50}$ (half maximum inhibitory concentration). We have performed up to three MTT assays for the cell lines using the ACH$3 \mathrm{P}$ cells, among them one has included the better results (Fig. 1).

\section{Data analysis}

All assays were done in three independent sets of experiments, and results were expressed as mean \pm SEM. Data of treated cells were compared with their respective controls and were analyzed using one-way analysis of variance with student t-test to determine the significance. In all cases, $\mathrm{p}<0.05$ were accepted as statistically significant. All statistical analysis was performed using Graph Pad 3.0 version.

\section{RESULTS}

The effect of $\mathrm{ADM}_{22-52}$ on $\mathrm{ACH}-3 \mathrm{P}$ cells viability was determined by MTT assay method

In this portion of the study, we evaluated the cytotoxicity effect by MTT assay. As shown in Fig. 2, MTT assay is a colorimetric assay employed for the determination of cell proliferation and cytotoxicity which is based on the reduction of the yellow-colored water-soluble tetrazolium dye MTT to formazan crystals. The inhibition of ACH-3P cells viability from the concentration of $5,25,50,75$, and $100 \mu \mathrm{M}$ of $\mathrm{ADM}_{22-52}$ after $24 \mathrm{~h}$ exposure was clearly visualized. Further, $\mathrm{ADM}_{22-52}$ cytotoxicity was clearly shown in Table 1 and the bar graph representation indicated

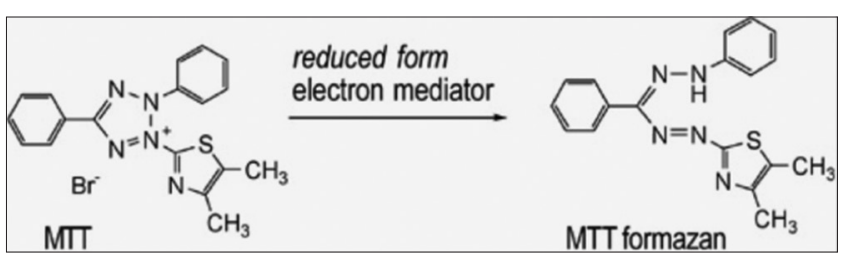

Fig. 1: Principle of MTT assay 
a significant difference in comparison to positive control $\left({ }^{*} \mathrm{p}<0.0001\right)$. These data were suggested the role of $\mathrm{ADM}_{22-52}$ in the invasion of firsttrimester trophoblast cells (Fig. 3).

Effect of $\mathrm{ADM}_{22-52}$ on sex steroid hormone levels in pregnant rats Progesterone and estrogen were estimated by CLIA by the method of Coombs et al. (1981). The tracer reagent consists of enzyme-labeled antibody and biotinylated monoclonal mouse anti-E2 and anti-PRG in buffer, dye, and preservative. After addition of tracer reagent to the sample, the plate was incubated for $20 \mathrm{~min}$ at room temperature. The values were expressed as $\mathrm{mIU} / \mathrm{ml}$. In our study, we evaluated that the $\mathrm{ADM}_{22-52}$ alters the synthesis of estrogens and progesterone during pregnancy and measured $17 \beta$ estradiol and progesterone in the serum from the control and $\mathrm{ADM}_{22-52}$-treated rat on day 9 of gestation. As shown in Fig. $4 \mathrm{a}$ and $\mathrm{b}$, infusion of $\mathrm{ADM}_{22-52}$ to pregnant rats from gestational day 9 caused a significant decline $(\mathrm{p}<0.0001)$ in the levels of both $17 \beta$-estradiol and progesterone. Furthermore, there was a

Table 1: Cell viability effects of $\mathrm{ADM}_{22-52}$ on $\mathrm{ACH}-3 \mathrm{P}$ cell line

\begin{tabular}{ll}
\hline Control & $\mathbf{1 0 0 \%}$ \\
\hline 5 & 71.02 \\
25 & 50.04 \\
50 & 41.05 \\
75 & 31.03 \\
100 & 18.21 \\
Camptothecin (anticancer drug) & 62.91 \\
IC $_{50}$ in $\mu \mathrm{M}$ & $36.4 \mu \mathrm{M}$ \\
\hline
\end{tabular}

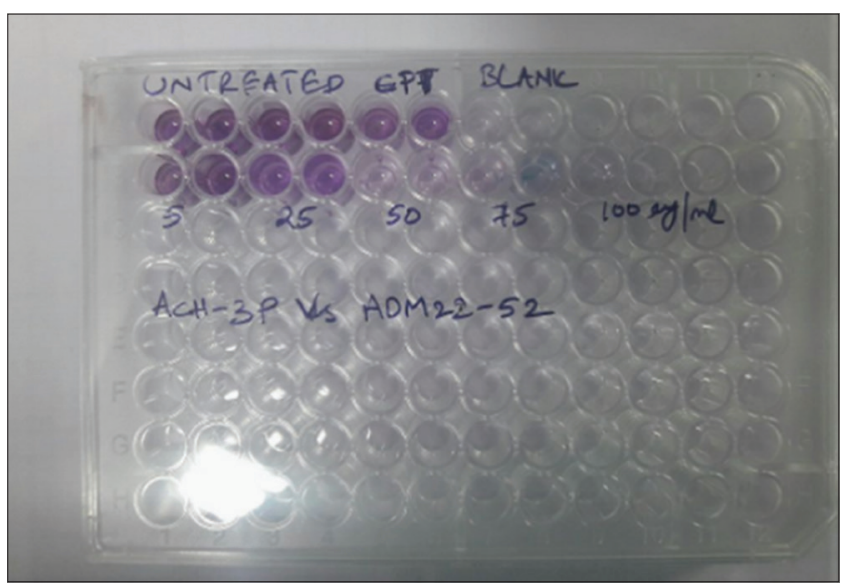

Fig. 2: MTT assay plate used to elucidate $\mathrm{IC}_{50}$ value

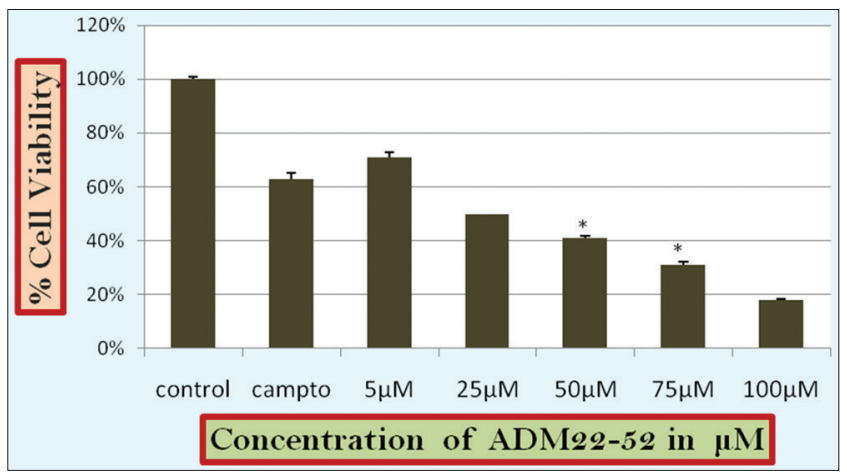

Fig. 3: ACH-3P cells viability graph in \% with relation to concentration. The inhibition of ACH-3P cells viability from the concentration of $5,25,50,75$, and $100 \mu \mathrm{M}$ of $\mathrm{ADM}_{22-52}$ after $24 \mathrm{~h}$ exposure. Each bar represents the data as the mean \pm SD of triplicate experiments and *indicates a significant difference in comparison to positive control $\left({ }^{*} \mathrm{p}<0.0001\right)$ tremendous decrease of serum progesterone and estrogen levels of $\mathrm{ADM}_{22-52}$ antagonist-treated high-dose group of rats $(250 \mu \mathrm{g} / \mathrm{rat} / \mathrm{day})$ than in low-dose rats $(125 \mu \mathrm{g} / \mathrm{rat} /$ day $)$ which are compared with that of the control group of rats.

Effects of $\mathrm{AM}_{22-52}$ on expression of the Bcl-2 and proapoptotic family of proteins in uteroimplanted tissues

To study the pathways involved in ADM antagonist-induced apoptosis in uteroimplanted tissue, we examined the Bcl-2 family of proteins which has been expressed to participate an imperative role in the regulation of apoptosis. In our current study, we have showed the pathways involved in $\mathrm{ADM}_{22-52}$-induced apoptosis and also have observed the changes in uteroimplanted regions of $\mathrm{ADM}_{22-52}$ treated in comparison with untreated control vehicle rats. Shown in Fig. 5. In the present study, we have distinctively shown the changes associated with $\mathrm{ADM}_{22-52}$ treatment in Bcl-2, Bax, caspase-3, and p53 proteins in uteroimplanted regions. The statistical analysis displayed that there was a significant difference in relative expression levels of active caspase-3, Bax, and p53, which was comparable with that of control groups of rats. Thus, there was a significant decrease in expression of the antiapoptotic $\mathrm{Bcl}-2$, but increase in expression levels was observed in the $\mathrm{ADM}_{22-52^{-}}$ treated group when compared with untreated controls.

\section{DISCUSSION}

Placental apoptosis is increased in vivo in preeclampsia (PE) and intrauterine growth restriction (IUGR). The cause and pathological implications of this phenomenon were unknown previously. Our current study was emphasized as on the apoptotic susceptibility of villous trophoblasts from normal, PE, and IUGR pregnancies. Cultured $\mathrm{ACH}-3 \mathrm{P}$ cell line formed an in vitro model of syncytialization which was experimentally used ultimately revealed that ADM is the crucial hormone during the preimplantation period and in trophoblast attachment to uterine endometrium and its differentiation. The present study was undertaken to demonstrate the expression and role of ADM in human placental cell line. After treating the cell line with $\mathrm{ADM}_{22-52}$ antagonist, cytotoxicity assessment was done to check the viability of
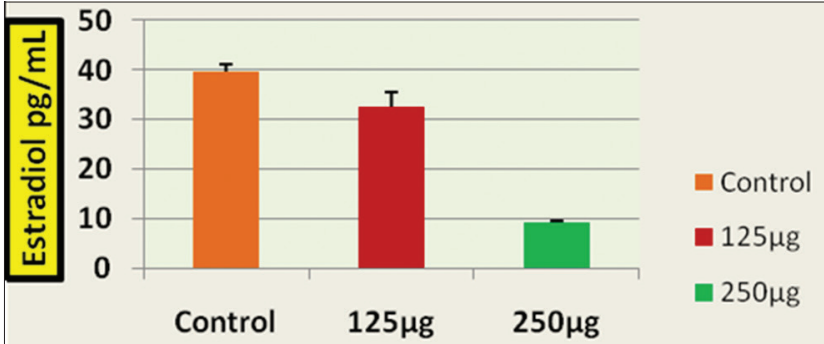

ADM22-52 treated group of rats

a

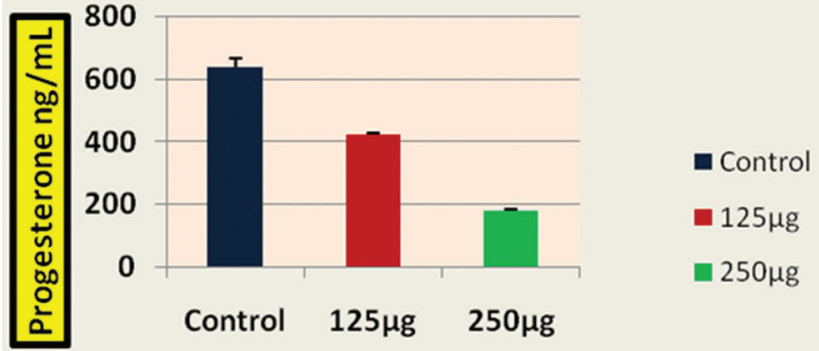

b

ADM22-52 treated group of rats

Fig. 4: ( $a$ and b) Steroidal hormones: Estrogen and progesterone activity levels in different serum samples of albino rats which were treated with ADM 22-52 antagonist and compared with that of control group of rats 


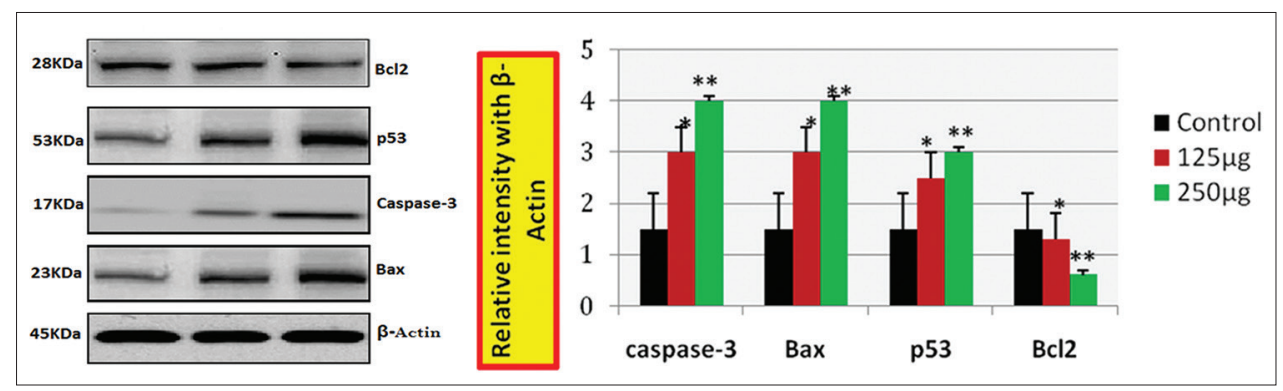

Fig. 5: Effect of $\mathrm{ADM}_{22-52}$ on the expression of apoptotic-related proteins (Bax, Bcl2, Caspase-3, and p53). Densitometry analysis of the respective protein bands normalized to $\beta$-Actin. Data are mean \pm SEM values for four replicate animals in each group. ${ }^{*} p<0.05,{ }^{* *} p<0.001$ indicates significantly difference compared with the control

the cells, and through graph, we plotted $\mathrm{IC}_{50}$ value. The $\mathrm{IC}_{50}$ value for low dose is $36 \mu \mathrm{M}$ and high dose is $62 \mu \mathrm{M}$.

In view of the fact that, pregnancy is a state during which the steroid hormone system experiences intense changes and is a most favorable physiological as well as dynamical model to investigate the steroid hormone balance which occurs during the course of pregnancy. To evince the significant role of ADM hormone, ADM antagonist was infused which crucially displayed with the aim to facilitate and recognize this hormone, which is considered to be the foremost essential hormone to sustain pregnancy. While Pepe et al. proposed that estrogen regulates uteroimplantation development, once the trophoblast attaches to uterine endometrium. Consequently, our present study suggests that any hormone imbalance in steroid hormones leads to IUGR as well PE not only during mid and late gestational period but also in early implantation period.

In our current study, we blocked the action of ADM using the endogenous inhibitor $\mathrm{ADM}_{22.52}$ which has important roles through sequestration in modulating bioavailability of VEGF [27] and ultimately resulted in hypoxic condition, thus declining the levels of estrogen and progesterone hormone which are very essential to sustain pregnancy. Therefore, the present study supported the previous studies of Penchalaneni et al. which clearly demonstrated the endogenous role of ADM, a novel peptide which is essential in regulation of the steroid hormones that are known to play a pivotal role not only in mid and late gestation but also during early implantation period to establish a successful pregnancy which results into a full term "Healthy Baby."

Several reports of previous studies displayed that there was a significant decrease in fetal and placental growth in pregnant rats when $\mathrm{ADM}_{22-52}$ was continuously infused from day 14 of gestation and several days after implantation and placental formation (Witlin et al., 2002 and Penchalaneni et al., 2004). Increase in fetal resorptions was not only observed in previous studies but also displayed in the current study. In the present study, we examined two problems, i.e. on infusion of $\mathrm{ADM}_{22-52}$ from day 2 of gestation abolished implantation formation and inhibited early embryo development and subsequently caused impairment of fetal development, and evinced the apoptotic pathways involved in the pathophysiology associated with fetal growth retardation in $\mathrm{ADM}_{22-52}$-treated rats. Second, even though $\mathrm{ADM}_{22-52}$ infusion did not completely abolish uteroimplantation formation, it severely reduced early implantation development and restricted fetal growth. Our results provided sturdy evidence that endogenous ADM is, indeed, indispensable for early implantation development and therefore also for fetal growth.

However, the adverse effects of $\mathrm{ADM}_{22-52}$ on both uterus and implantation development were apparent with the groups given $125 \mu \mathrm{g} / \mathrm{rat} /$ day as the lowest dose and $250 \mu \mathrm{g} / \mathrm{rat} /$ day as the highest dose used in the present study.

\section{CONCLUSION}

In the present study, we have demonstrated that ADM, a novel member of the calcitonin-related family of peptides has a crucial role in pregnancy and is imperative for uteroimplantation growth and fetal development. Infusion of $\mathrm{ADM}_{22-52} 250 \mu \mathrm{g} / \mathrm{rat} /$ day to pregnant rats on day 2-8 of gestation caused a significant decrease in uterus and implants weights than $125 \mu \mathrm{g} / \mathrm{rat} /$ day and consequently increased in resorption sites. Therefore, ADM was not only important in mid and late gestational period, but that it also played a critical role during preimplantation period, as brief inhibition of ADM action by $\mathrm{hAM}_{22-52}$ during this period by restricting uteroimplanted sites growth and increasing fetal resorption in early pregnancy/early implantation.

In western blot analysis, it has been clearly demonstrated that the expression levels of caspase-3, bax, and p53 have been significantly increased in ADM-treated group and $\mathrm{Bcl} 2$ protein expression decreased; the results clearly signified that ADM is main hormone in early implantation period. In conclusion, based on the present study, it has been proposed that the antagonist actions of ADM have distinctively shown the lowered Bcl-2 expression in uteroimplanted tissues which would allow cytochrome $c$ release from mitochondria to initiate the cascade of caspase activation and cell death. Several proapoptotic members, such as Bax and p53, have been reported to induce cytochrome $c$ release from mitochondria. Taking into account the previous work and present work together, it has been acknowledged that the administration of ADM antagonist into pregnant rats at early implantation period induced apoptosis. It has been suggested that the inhibitory actions of endogenous ADM in pregnant rats would result in dysregulation of apoptosis in uteroimplant region, which would lead to FGR.

A number of mechanisms have been portrayed in the pathophysiology of pregnancy complications, such as intrauterine growth retardation, gestational hypertension, and PE. We proposed that one such mechanism was intensified apoptosis caused by decrease in the levels of ADM during pregnancy. There is an assembly of genetic, physiologic, and environmental factors that must all work together in perfect synchronization throughout pregnancy to create the magic so-called "miracle" that is a healthy well growth baby. Any irregularity in this process might result in pregnancy complications, which can include implantation failure, miscarriage, fetal growth restriction, gestational diabetes, $\mathrm{PE}$, and preterm birth. Given in this complexity, there is a contemporarily a major interest in ADM and its efforts have been put forth in the field, to expand our understanding of the factors that contribute to healthy versus unhealthy pregnancies.

The indigenous role of ADM in pre-implantation period is well pioneered in our study. We have revealed the deleterious effects of ADM antagonist on developing blastocyst, which were carried out in our in vitro cell line work. The antagonism of ADM function in vivo and in vitro has provided a strong evidence that ADM function during the pre-implantation period and is essential for normal pregnancy as well healthy pregnancy which results in full-term baby.

\section{FUNDING}

These studies were supported by DST-SERB, New Delhi, for providing financial support in project by releasing funds timely Project Ref. No.: SB/SO/AS-080/2013. 


\section{CONFLICTS OF INTEREST}

The authors that there were no conflicts of interest.

\section{REFERENCES}

1. Di Iorio R, Marinoni E, Letizia C, Villaccio B, Alberini A, Cosmi EV, et al. Adrenomedullin production is increased in normal human pregnancy. Eur J Endocrinol 1999;140:201-6.

2. Di Iorio R, Marinoni E, Letizia C, Cosmi EV. Adrenomedullin in perinatal medicine. Regul Pept 2003;112:103-13.

3. Filippatos GS, Gangopadhyay N, Lalude O, Parameswaran N, Said SI, Spielman W, et al. Regulation of apoptosis by vasoactive peptides. Am J Physiol Lung Cell Mol Physiol 2001;281:L749-61.

4. Garayoa M, Bodegas E, Cuttitta F, Montuenga LM. Adrenomedullin in mammalian embryogenesis. Microsc Res Tech 2002;57:40-54.

5. Kobayashi K, Kubota T, Aso T, Hirata Y, Imai T, Marumo F, et al. Immunoreactive adrenomedullin (AM) concentration in maternal plasma during human pregnancy and AM expression in placenta. Eur J Endocrinol 2000;142:683-7.

6. Minegishi T, Nakamura M, Abe K, Tano M, Andoh A, Yoshida M, et al. Adrenomedullin and atrial natriuretic peptide concentrations in normal pregnancy and preeclampsia. Mol Hum Reprod 1999;5:767-70.

7. Di Iorio R, Marinoni E, Cosmi EV. New peptides, hormones and parturition. Gynecol Endocrinol 1998;12:429-34.

8. Moriyama T, Otani T, Maruo T. Expression of adrenomedullin by human placental $\backslash$ cytotrophoblasts and choriocarcinoma J Ar cells. J Clin Endocrinol Metab 2001;86:3958-61.

9. Hinson JP, Kapas S, Smith DM. Adrenomedullin, a multifunctional regulatory peptide. Endocr Rev 2000;21:138-67.

10. Kangawa K, Kitamura K, Minamino N, Eto $T$, Matsuo $H$. Adrenomedullin: A new hypotensive peptide. J Hypertens Suppl 1996;14:S105-10.

11. Kitamura K, Kangawa K, Matsuo H, Eto T. Adrenomedullin. Implications for hypertension research. Drugs 1995;49:485-95.

12. Champion HC, Fry RC, Murphy WA, Coy DH, Kadowitz PJ. Catecholamine release mediates pressor effects of adrenomedullin-(15-22) in the rat. Hypertension 1996;28:1041-6.

13. Santiago JA, Garrison E, Purnell WL, Smith RE, Champion HC, Coy $\mathrm{DH}$, et al. Comparison of responses to adrenomedullin and adrenomedullin analogs in the mesenteric vascular bed of the cat. Eur J Pharmacol 1995;272:115-8.

14. Macri CJ, Martinez A, Moody TW, Gray KD, Miller M, Gallagher M, et al. Detection of adrenomedullin, a hypotensive peptide, in amniotic fluid and fetal membranes. Am J Obstet Gynecol 1996;75:906-11.

15. Parr EL, Tung HN, Parr MB. Apoptosis as the mode of uterine epithelial cell death during embryo implantation in mice and rats. Biol Reprod
1987;36:211-25.

16. Schlafke S, Welsh AO, Enders AC. Penetration of the basal lamina of the uterine luminal epithelium during implantation in the rat. Anat Rec 1985;212:47-56

17. Welsh AO, Enders AC. Chorioallantoic placenta formation in the rat: I. Luminal epithelial cell death and extracellular matrix modifications in the mesometrial region of implantation chambers. Am J Anat 1991;192:215-31.

18. Putcha GV, Harris CA, Moulder KL, Easton RM, Thompson CB, Johnson EM Jr. Intrinsic and extrinsic pathway signaling during neuronal apoptosis: Lessons from the analysis of mutant mice. J Cell Biol 2002; 157:441-53.

19. Zimmermann KC, Bonzon C, Green DR. The machinery of programmed cell death. Pharmacol Ther 2001;92:57-70.

20. Denault JB, Salvesen GS. Caspases: Keys in the ignition of cell death. Chem Rev 2002;102:4489-500.

21. Antonsson B, Martinou JC. The Bcl-2 protein family. Exp Cell Res 2000;256:50-7.

22. Zou H, Henzel WJ, Liu X, Lutschg A, Wang X. Apaf-1, a human protein homologous to $C$. elegans CED-4, participates in cytochrome c-dependent activation of caspase-3. Cell 1997;90:405-13.

23. Marcondes FK, Bianchi FJ, Tannon AP. Determination of estrous cycle phase of rats: Some helpful considerations. Braz J Biol 2002;62:609

24. Spornitz UM, Socin CD, David AA. Estrous stage determination in rats by means of scanning electron microscopic images of uterine surface epithelium. Anat Res 1999;254:116-26.

25. Penchalaneni J, Wimalawansa SJ, Yallampalli C. Adrenomedullin antagonist treatment during early gestation in rats causes fetoplacental growth restriction through apoptosis. Biol Reprod 2004;71:1475-83.

26. Witlin AG, Li ZY, Wimalawansa SJ, Grady JJ, Grafe MR, Yallampalli C. Placental and fetal growth and development in late rat gestation is dependent on adrenomedullin. Biol Reprod 2002;67:1025-31.

27. Ahmad S, Ahmed A. Antiangiogenic effect of soluble vascular endothelial growth factor receptor-1 in placental angiogenesis. Endothelium 2005;12:89-95.

28. Pepe GJ, Billiar RB, Leavitt MG, Zachos NC, Gustafsson JA, Albrecht ED. Expression of estrogen receptor $\alpha$ and $\beta$ in the baboon fetal ovary. Biol Reprod 2002;66:1054-60.

29. EL-Din EY, Omar AR. Effect of prenatal administration of therapeutic dose of topiramate on placentae albino rats fetuses. Int J Pharm Pharm Sci 2017;9:54-9.

30. Deshpande P, Mohan V, Pore M, Gumaste S, Thakurdesai P. Prenatal developmental toxicity evaluation of low molecular weight galactomannans based standardized fenugreek seed extract during organogenesis period of pregnancy in rats. Int $\mathrm{J}$ Pharm Pharm Sci 2016;8:248-53. 